\title{
Mapping food availability and food scarcity in migrants' hometown
}

\author{
Didit Purnomo $^{1}$, Indah Susilowati ${ }^{2}$, F.X. Sugiyanto ${ }^{3}$ \\ ${ }^{1}$ Department of Economics, Muhmmadiyah University of Surakarta, Surakarta, Indonesia. \\ ${ }^{2,3}$ Department of Economics, Diponegoro University, Semarang, Indonesia. \\ e-mail: dp274@ums.ac.id
}

\section{Article Info}

Article history:

Received : 20 January 2014

Accepted : 10 Jully 2014

Published: 1 October 2014

Keywords:

food availability, food security, food scarcity and surplus, central migrant

JEL Classification:

Q180, L66, Q1

DOI:

http://dx.doi.org/10.20885/ejem .vol6.iss $2 . \operatorname{art} 3$

\begin{abstract}
The research aims to map and analyze food scarcity or surplus based on the food availability at migrant area in Wonogiri, Central Java. The rapid rural assessment and focus group discussion were used for detecting and exploring any food plant that is good and appropriate to the characteristics of migrant area. The condition of food availability in the Wonogiri regency could be stated to be surplus. The highest surplus was located in Giriwono sub-district and the lowest surplus in Bulukerto sub-district. Most of the sub-districts in Wonogiri subdistricts reached an IFI score $<0.5$ (index of composite food security) in which it could represent a secure condition.
\end{abstract}

\begin{abstract}
Abstrak
Penelitian ini bertujuan untuk memetakan dan menganalisis kelangkaan pangan atau surplus berdasarkan ketersediaan pangan di daerah migran. Itu terletak di Kabupaten Wonogiri, Jawa Tengah Indonesia. Penelitian ini menggunakan pendekatan kualitatif untuk menganalisis tujuannya. Penilaian dan diskusi kelompok pedesaan yang cepat yang digunakan untuk mendeteksi dan menjelajahi setiap tanaman pangan yang baik dan sesuai dengan karakteristik daerah migran pusat. Kondisi ketersediaan pangan di Kabupaten Wonogiri dapat dinyatakan sebagai surplus. Surplus tertinggi terletak di kecamatan Giriwono dan surplus terendah di Kecamatan Bulukerto. Sebagian besar kecamatan di Wonogiri kecamatan mencapai skor IFI <0,5 (indeks ketahanan pangan komposit) di mana ia bisa mewakili kondisi aman.
\end{abstract}

\section{Introduction}

Food is a very strategic commodity of nation and primary need for human beings (Indrawan, 2012). It is consistent to Act No. 18/2012 about Food, stipulating that the government rules and regulates, develops, controls and supervises food while people produce, provide and distribute it as well as serve as a consumer who has a sufficient, nutritious, diverse, and secure food where they can buy it.

As a strategic commodity, food availability must be a priority for regional and national development. It is greatly intended to meet people's food needs as a human being's primary need, particularly.
In line with population growth and social condition, sufficient, secure, and nutritious food availability are more increasingly needed. An individual's insufficient food can reflect people's insufficient one. Some actions in the actualization of food availability can be a pattern of various food consumption rooted in people as a local wise (Rauf and Lestari, 2009). The research of food plant development at dry land in Merauke (Djaenudin, 2008) in Merauke shows that the results of the food plant commodities - particularly ground nut and cassava were developed with the provision of fertilizers in consideration with the quality of land characteristics. In an agricultural pro- 
duction process, it is necessary to utilize a variety of food plants and lands. The food security through a variety of food plants was achieved with land utilization. The land utilization with the characteristics of plant life cycle will produce an optimal (Rayes, 2007; Marfai and Chayadi, 2012) and can keep a sustainable food plant in the future. In other words, a less maximum food land can cause low land productivity.

Food plant development is greatly intended to increase productivity, production, efficiency, and added value for competition so that it can raise farmers' and people's incomes. However, the question is closely related to the different geographic condition of each area. The areas with unproductive and infertile dry land and lack of sufficient irrigation will get a specific attention in consideration with food scarcity.

The study aims to map an extent of food scarcity for each area in terms of food availability and an attempt to be taken in relation to an area's characteristics. It was located in Wonogiri regency where it is an agricultural land and a central migrant. Furthermore, it possesses many labors for utilizing their agricultural lands. On the other side, nevertheless, more labors in the area migrate to other areas or foreign countries for making a better earning (Purnomo, 2009). A logic decision they take is very difficult to influence because they think that working in other areas or foreign countries will cause them to make a better living. If it happens continuously, this will make a kind of labor transfer from a rural area to urban one. It can indirectly take an impact on a low productivity of agricultural lands, particularly food plants in the areas with potential food plants. Then, if the productivity of agricultural lands is low, it will cause not to achieve a food availability of the areas

Ariani (2007) stated that food availability is an essential prerequisite for consumption sustainability, but it is insufficient in food security context because there are many variables for the achievement of food security in an area and household level. Although food availability is nationally abundant but if a province (area) can't get access to it, it will take a food scarcity. It means that the food availability is said to be a 'problem.' The problem can be how the condition of food security and food surplus can be seen on the basis of the central migrant area level?

\section{Food availability and Food Security}

A concept and attempt to actualize a national food security had begun since early independent day; then it was completed until Indonesia could actualize the selfsufficiency in food in 1984. However, population density and development of socioeconomic and political activities has cause very complex problems that greatly influence the actualization of national food security.

Food crisis in various countries such as in Indonesia indicates that food security must greatly be actualized. It may be achieved by providing national human resources in consideration with a variety of areas because depending on imported food can cause high scarcity or insufficiency. No countries can run a sustainable development without previously solving a food security. Therefore, the actualization of food security taking a rest on self-sufficiency in food, institution, and local culture has been a commitment of central and local governments with wide community that runs in a food field.

Food availability is one of the elements in a food concept. Referring to the definition of FAO, food security is supported by the trilogy (triad concepts): (1) food availability, (2) food access, and (3) food utilization (Simatupang, 2008: 9). It is the three elements that are a fundamental determinant of food security. The food availability refers to sufficient food access for the population. The food access refers to the capacity to gaining food access with 
exchange media (market) or transfer (institution). Food utilization refers to an allocation process and food access production so that an individual can gain sufficient. The elements are related to one another in hierarchy. Food availability is a substantial prerequisite, but it can't secure sufficient food access.

If the food availability is insufficient, the food access must also be insufficient. However, although the food access availability is abundant, the food access will be sufficient. The food access is a substantial prerequisite for fulfilling sufficient food. If the food access (for example, the household's food access) is insufficient, its allocation for consumption by individual households must be insufficient. Although the food access is abundant, if it is not allocated and produced with actual food consumption, the consumption will be insufficient. The interrelation of the substantial determinants can be seen in Figure 1. The trilogy of the food security can be called as an essential and sufficient prerequisite for the achievement of food security.

Food availability is an essential prerequisite for sustainable consumption, but it is not sufficient in food security context because there are many variables for the achievement of food security in an area and household level (Ariani, 2007). Therefore, the government has taken some actions for nationally fulfilling food needs. If there is a food surplus, the food can be distributed or traded in areas with food deficit and export. On the other hand, if there is a food deficit, few food accesses for national consumption can be provided with import.

Sustainable food security by increasing national food availability, particu- larly rice, as well as farmers' incomes and welfare makes a long- and short-term policy. In a short-term policy, it is necessary to protect them from excessively importing rice and it should be supported with a policy that can result the increase in productions of domestic rice in an area where the farmers produce the rice traditionally. In a long-term policy, the limited import of rice can be decreased gradually, but a policy of the increase in domestic production must be taken and it must be accompanied with diverse consumptions or foods so that it can decrease the dependency on one of food production, particularly rice. Consequently, diverse availabilities of food access also need to be increased by developing agroindustries of non-rice production based on domestic product so that it is easily accessible anytime and anywhere. The agroindustry is greatly intended to develop a household agro-industry so that it can raise a household's welfare in an urban in general, and a farmer's one in particular (Darwanto, 2005).

\section{Production in the achievement food se- curity availability}

Rugian states (2013) that the term production is an economic activity with some units and inputs to reach a final result. It means that a production process takes a correlation between the utilizations of some production factors with products. Three main problems of production activity are as follows: 1) what and how many will be produced, 2) how to produce goods and services, and 3) for whom are the goods and services?

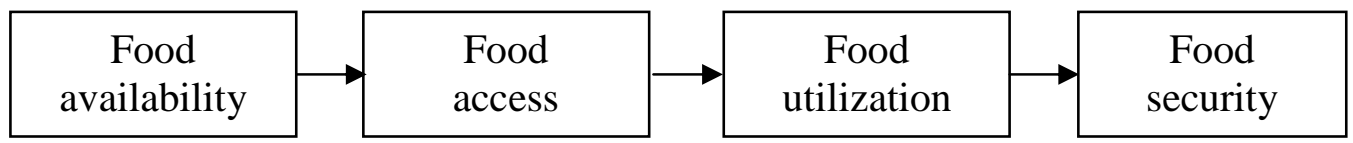

Figure 1. The Interrelation of the Food Security Trilogy, Consisting of the Components: Food Availability, Food Access and Food Utilization (Simatupang, 2008) 
The problems what and how many refer to the effort for achieving production availability. A food plant is a solution to the problems (what and how many will be produced): as the amount of food availability to be produced. In terms of food security achievement, an agricultural production process can employ a technique to reach a product and community empowerment through an institution to maximize a product.

In his research Darwanto (2005) suggests that food commodity is categorized as a subsistent commodity because a product $(\mathrm{Q})$ is used to meet food security for producers' or farmers' families (C) and the others for markets (M). Systematically, the allocation can be described as follows: $\mathrm{Q}=\mathrm{C}+\mathrm{M}$

\section{Land utilization in the achievement of food plant availability}

Agriculture is a very essential sector for Indonesian economy. Diverse characteristis of land resources in Indonesia are potentially used for producing a variety of good agricultural commodities supported with the condition of agro-ecosystem. Based on land size and diverse agroecosystem, their development is very great. However, the agricultural sector has not been significant in raising farmers' welfare, meeting one's own needs, generating Indonesian welfare and investment (Roja, 2009). The section will describe land function and land problem in definition.

In relation to natural resources, the terms soil and land is not clear. Actually, the word land expresses a broader meaning than the word soil. Land resources are a physical environment of climate, topography, soil, hydrology, and vegetation in which a given boundary influences a capacity of land use (Rayes, 2007). Furthermore, Rayes states that a land functions as 1) production (a basis for life supporting system), 2) biotic environment (a habitat of biology), 3) climate (a source and sink of glasshouse gas), 4) hydrology, and 5) storing.
Based on the functions, a land can be utilized as production area through institution empowerment, intended to achieve a food security. To see a problem of land use, therefore, is necessary to see its present use, evaluate whether it is optimally and efficiently used, and identify how it can be utilized. There will not be a problem if the production area is not settled by people; but, if people have settled it, it is very necessary to make a stage of diagnosis with the problem because without the identification of problem and analysis of its cause, it is impossible for us to plan a land use. There are three methods that can be used to analyze a problem of land use: 1) farming system analysis, 2) diagnosis and design, and 3) rapid rural appraisal (Hardjowigeno, 2007).

The farming system analysis refers to an agricultural business with a kind of land use, environment and economy, including a business owner, used land and planting system or livestock production of whether it is intended to meet his own needs or it is sold. The system of farming analysis is taking a decision and using an agricultural-based land. It is an analysis of farmer's difficulty. The result of analysis, then, is used to choose a technology and apply it for solving the problem.

The diagnosis and design (D\&D) is an approach and method for diagnosing a problem of land use and designing its use system for solving the problem. In the early, the method is developed to design agroforestry system and can be useful for another land use.

The rapid rural appraisal is an exploratory survey procedure by a team of multi-disciplines to develop any overview of local land use. The physical and socioeconomic activity includes data review, observation and interview with land users and local government staff.

\section{Research Method}

The research was located in Wonogiri regency, Provincial Central Java. It is due to 
the following argumentations. First, the regency is an agricultural and central migrant area that can potentially meet food availability and food security for itself and its surrounding. Second, it is indicated that there is a labor transfer from hometown area (research location) to other areas. It can cause land productivity to fall so that it will disturb an achievement of food security optimally. Third, the regency's subdistricts are geographically a dry land to be properly utilized for food plant production.

The data of the study included a primary and secondary. The informants covered the key people (figures). They were the officials of Food Security Agency and some representatives of farmer group association (FGD results).

Food availability is the physical food availability in an area from all sources, domestic (net) food production, food trade and food aid. It is determined by food productions in the area, food trades through mechanism in the area, traders' stocks, and government's reserves or other organizations.

The discussion of the potential food security refers to a calculation approach of food availability ratio and composite food security index. The ratio can be calculated with the formulation:

Food consumption availability ratio $\left(\mathrm{I}_{\mathrm{AV}}\right)$

$$
\mathbf{I}_{\mathbf{A V}}=\frac{\mathbf{C}_{\text {norm }}}{F}
$$

Cnorm: Normatif consumtion (300 gram);

\section{F : Serealia food availability}

If the value of availability ratio ' $\mathrm{I}_{\mathrm{AV}}$ ' is more than one, all the areas are deficit food of serelia, or the normativeconsumptive need can't be met from the net productions of serelia and if ' $\mathrm{I}_{\mathrm{AV}}$ ' is less than 1, it indicates that the surplus food of serelia happens in the are.

The composite food security indexis determined with 9 indicators of chronic food scarcity.
$\mathrm{IFI}=1 / 9\left(I_{A V}+I_{B P L}+I_{R O A D}+I_{E L E C}+I_{L I T}+\right.$

$$
\left.I_{L E X}+I_{N U T}+I_{\text {WATER }}+I_{\text {HEALTH }}\right)
$$

\section{Result and Discussion \\ Research location}

The research was located in Wonogiri regency, Provincial Central Java. The area is situated at Eastern South of the Province. It is bordered to Pacitan regency (at South) of Provincial East Java and Indonesian Ocean, Sukoharjo regency, Karanganyar regency, and Magetan regency of Provincial East Java (at North), Karanganyar regency and Ponorogo regency of Provincial East Java (at East), and Special District of Yogjakarta (at West).

Wonogiri regency is located between $7^{0} 32^{\prime}-8^{0}$ north latitude and $110^{\circ} 41^{\prime}$ - $111^{0} 18^{\prime}$ east longitude. The condition of its nature is a limestone-related mountain range, particularly at the South. It is very close to Seribu Mountain Range to be a source of Bengawan Solo River.

Administratively, the regency consists of 25 sub-districts. In 2011, its land size reached by $18,236.02$ ha with the smallest Puhpelem subdisrict and widest Pracimantoro sub-district

It contains the kinds of lands that cause their different use. As an agrarian area with the population of making a living in agriculture, its majority of land is the rice fields of 32,342 ha (or 17.75\%) and the dry land of 149,894 ha (or $82.25 \%$ ) in size.

\section{Mapping food availability scarcity in Wonogiri regency}

The study aims to map food availability in Wonogiri regency. It was based on carbohydrate food sufficiency. The food is rooted in the production of primary food soft serelia: rice, corn, tuber (sweet potato, cassava) utilized to fulfilling food sufficiency. Based on the data, the extent of food scarcity will can be classified into surplus and minus conditions. The following Table 1 describes the surplus and minus food availability in Wonogiri regency reports. 
Table1: Surplus and Minus Food Availability in Wonogiri Regency in 2011

\begin{tabular}{clcclc}
\hline No & Sub-districts & $\begin{array}{c}\text { Total Amounts } \\
\text { (in ton) }\end{array}$ & No & Sub-districts & $\begin{array}{c}\text { Total Amounts } \\
\text { (in ton) }\end{array}$ \\
\hline 1 & Pracimantoro & 113508 & 14 & Wonogiri & 33707 \\
2 & Paranggupito & 34067 & 15 & Ngadirojo & 112857 \\
3 & Giritontro & 38178 & 16 & Sidoharjo & 61132 \\
4 & Giriwoyo & 131333 & 17 & Jatiroto & 88754 \\
5 & Batuwarno & 91923 & 18 & Kismantoro & 27975 \\
6 & Karangtengah & 46246 & 19 & Purwantoro & 33844 \\
7 & Tirtomoyo & 54511 & 20 & Bulukerto & 24029 \\
8 & Nguntoronadi & 35075 & 21 & Puhpelem & 32103 \\
9 & Baturetno & 45573 & 22 & Slogohimo & 94157 \\
10 & Eromoko & 46989 & 23 & Jatisrono & 37676 \\
11 & Wuryantoro & 52220 & 24 & Jatipurno & 24385 \\
12 & Manyaran & 70469 & 25 & Girimarto & 72150 \\
13 & Selogiri & 43310 & & & \\
\hline
\end{tabular}

Source: WDA 2011-2012, in process

Based on the data in Table 1, it can generally be stated that the food availability in Wonogiri regency is in a surplus condition. The highest surplus is located in Giriwoyo, Pracimantoro, and Ngadirojo subdistricts; the lowest surplus is situated in Bulukerto sub-district. The locations of the sub-districts can be seen in Figure 2.

\section{Analysis result of food availability and food security}

The map of the food scarcity is determined with the combination of the 9 indicators.

\section{Analysis result of food availability ratio}

An analysis result of the food availability ratio in each sub-district of Wonogiri regency is reported in Table 2.

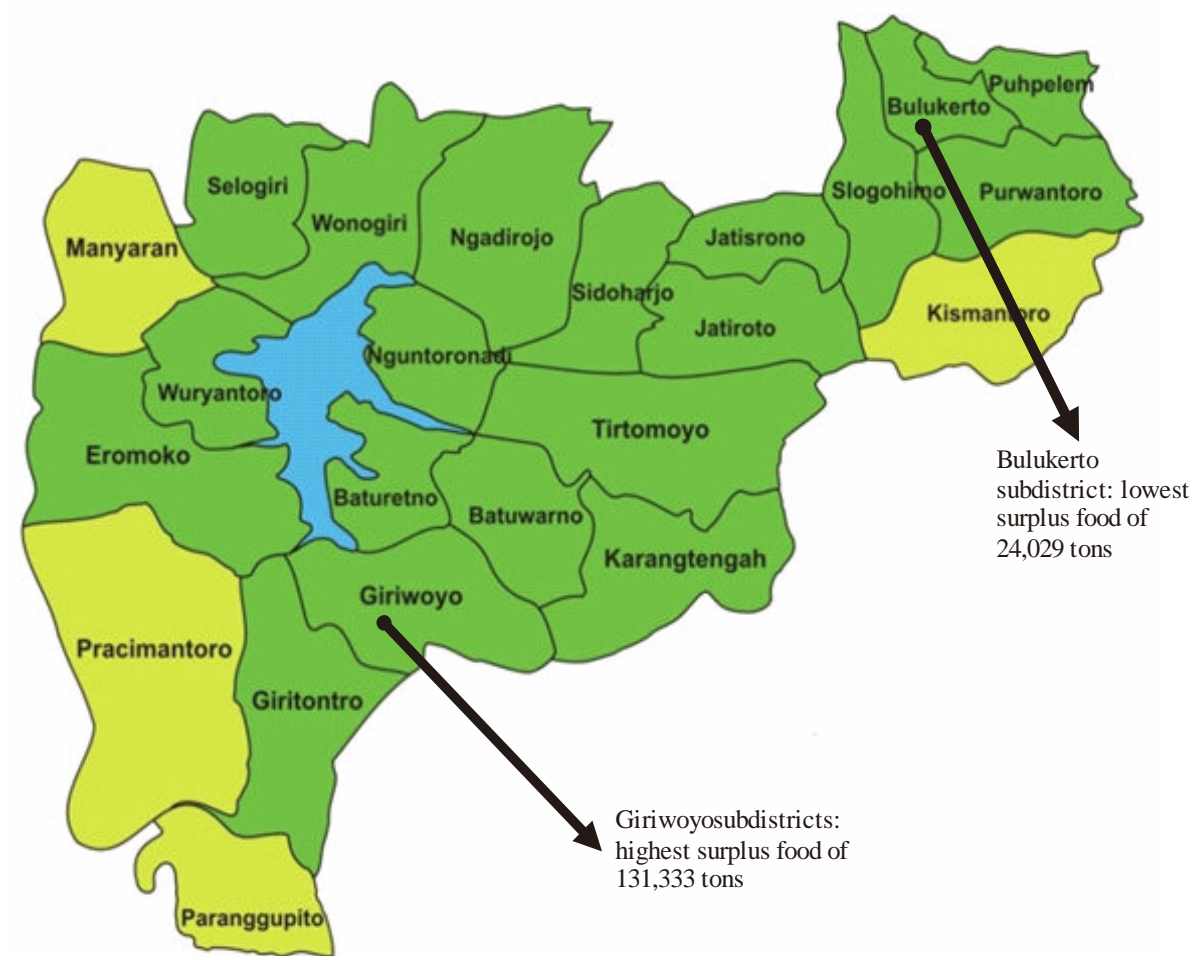

Figure 2: Map of Surplus and Minus Food Scarcity in Wonogiri Regency (2011-2012) 
Table2: Food Availability Ratio in Wonogiri Regency (2010-2011)

\begin{tabular}{lccllcc}
\hline \multirow{2}{*}{ Sub-districts } & \multicolumn{2}{c}{$\mathbf{I}_{\mathbf{A V}}$} & & \multirow{2}{*}{ Sub-districts } & \multicolumn{2}{c}{$\mathbf{I}_{\mathbf{A V}}$} \\
\cline { 2 - 3 } \cline { 6 - 7 } & $\mathbf{2 0 1 0}$ & $\mathbf{2 0 1 1}$ & & $\mathbf{2 0 1 0}$ & $\mathbf{2 0 1 1}$ \\
\hline 1. Pracimantoro & 0,21 & 0.22 & & 14. Wonogiri & 0,68 & 0.99 \\
2. Paranggupito & 0,15 & 0.20 & & 15. Ngadirojo & 0,25 & 0.30 \\
3. Giritontro & 0,23 & 0.21 & & 16. Sidoharjo & 0,28 & 0.38 \\
4. Giriwoyo & 0,19 & 0.20 & & 17. Jatiroto & 0,34 & 0.32 \\
5. Batuwarno & 0,10 & 0.08 & & 18. Kismantoro & 0,28 & 0.68 \\
6. Karangtengah & 0,01 & 0.00 & 19. Purwantoro & 0,48 & 0.58 \\
7. Tirtomoyo & 0,33 & 0.44 & 20. Bulukerto & 0,45 & 0.55 \\
8. Nguntoronadi & 0,37 & 0.44 & 21. Puhpelem & 0,20 & 0.25 \\
9. Baturetno & 0,63 & 0.74 & 22. Slogohimo & 0,49 & 0.44 \\
10. Eromoko & 0,26 & 0.40 & 23. Jatisrono & 0,90 & 1.00 \\
11. Wuryantoro & 0,31 & 0.30 & 24. Jatipurno & 0,53 & 0.72 \\
12. Manyaran & 0,29 & 0.38 & 25. Girimarto & 0,48 & 0.44 \\
13. Selogiri & 1,00 & 0.97 & & & \\
\hline
\end{tabular}

Note: $I_{A V}=$ Food Availability Index

Source: Bappeda, Pemkab Wonogiri 2012

Based on Table 2, it is reported that a food security in all the sub-districts of Wonogiri regency was in surplus food of serelia during 2010. It has particularly occurred in Karangtengah sub-district where the food security of the sub-district reached by 0.01 and could be categorized into very high; but, in Selogiri sub-district it reached a food availability ratio of 1.00 and could be grouped into deficit. In general, however, it was in surplus condition.

During 2011, there was a change in food availability. The food availability of Karangtengah and Batuwarno sub-districts reached the highest surplus, but Selogiri, Wonogiri and Jatisrono sub-districts were nearly deficit in food availability. In general, however, the condition of Wonogiri regency was relatively secure (based on the value of $\mathrm{I}_{\mathrm{AV}}$ ).

The shift of $I_{A V}$ value relates to the amount of the population in consumption and food plant availability, included at central migrant. In 2013, the dynamics of the population at central migrant fell. The farmers' characteristics of migrants' families average 46 years old: the oldest of 58 and the youngest of 30 . The lowest and highest education level of the respondents graduates from Junior High School and University.
In the survey, the other characteristics of central migrant worked as a farmer, entrepreneur, administrative staff and businessman, and had previously migrated and worked as a farmer, blue-collar employee, broker (intermediary in sales) and entrepreneur.

The migrants left hometown for urban areas, mainly due to economy for generating capital. After that, they went home and did not live there. The capital was used for land development and quality. It can really support a food security at central migrant.

\section{Analysis Result of Composite Food Secu- rity Index}

A composite food security index comprises 9 indicators of food scarcity: 1) food availability index $\left.\left(\mathrm{I}_{\mathrm{AV}}\right), 2\right)$ poor population index under poverty level (IBL), 3) village index without street access ((IROAD), 4) household index without electricity (IELEC), 5) illiterate female index (ILIT), 6) survival index (ILEX), 7) under 5-year old baby weight index (INUT), 8) household index without fresh water access (IWATER), and 9) household index with $>5 \mathrm{~km}$ distance from medical healthy facility. Based on the data of WDA data and FGD, it is found a scoring of food security and scarcity in Wonogiri regency as a basis for Composite Security Index (IFI) calculation. 
Table3: Results of Composite Food Security Index in all the Sub-districts of Wonogiri Regency (2010-2011)

\begin{tabular}{lccllll}
\hline \multirow{2}{*}{ Sub-districts } & \multicolumn{2}{c}{ IFI } & \multirow{2}{*}{ Sub-districts } & \multicolumn{2}{c}{ IFI } \\
\cline { 2 - 3 } \cline { 6 - 7 } 1. Pracimantoro & $\mathbf{2 0 1 0}$ & $\mathbf{2 0 1 1}$ & & $\mathbf{2 0 1 0}$ & $\mathbf{2 0 1 1}$ \\
2. Paranggupito & 0,34 & 0.40 & 14. Wonogiri & 0,38 & 0.32 \\
3. Giritontro & 0,57 & 0.45 & & 15. Ngadirojo & 0,35 & 0.24 \\
4. Giriwoyo & 0,57 & 0.28 & 16. Sidoharjo & 0,33 & 0.19 \\
5. Batuwarno & 0,39 & 0.29 & 17. Jatiroto & 0,40 & 0.17 \\
6. Karangtengah & 0,36 & 0.20 & 18. Kismantoro & 0,56 & 0.37 \\
7. Tirtomoyo & 0,45 & 0.25 & 19. Purwantoro & 0,46 & 0.27 \\
8. Nguntoronadi & 0,37 & 0.23 & 20. Bulukerto & 0,44 & 0.32 \\
9. Baturetno & 0,51 & 0.25 & 21. Puhpelem & 0,33 & 0.28 \\
10. Eromoko & 0,41 & 0.23 & 22. Slogohimo & 0,36 & 0.27 \\
11. Wuryantoro & 0,40 & 0.24 & 23. Jatisrono & 0,48 & 0.27 \\
12. Manyaran & 0,50 & 0.27 & 24. Jatipurno & 0,47 & 0.27 \\
13. Selogiri & 0,47 & 0.36 & 25. Girimarto & 0,32 & 0.22 \\
\hline
\end{tabular}

Note: $I F I$ = Composite Food Security

Source: Bapedda, Pemkab Wonogiri 2012

The analysis results of composite food security index in all the sub-districts of Wonogiri regency are reported in Table 3. In Table 3, it is described that during the survey the food availability in all the subdistricts of Wonogiri regency could be stated to be secure. Nearly all of the subdistricts reached a value under 0.5 where it is considered as secure. Based on the value of IFI, thus, the food availability of Wonogiri regency was tendentiously secure.

The food security at central migrant as calculated with Composite Security Index (IFI) above is described as increasingly better. The higher the IFI value or close to 1 is, the more food scarcity the area in the category is. In general, the sub-districts of Wonogiri regency increased in the food security achievement. One subdistrcit (Pracimanoto) had an increased IFI index. It means that the areas could be categorized as food scarcity.

One of the determinant factors in the successfulness of the food security is related to the human resources and institutional empowerment. A policy strategy of effective and efficient national food security can only be formulated with the proper paradigm. The paradigm of food security will continually be developing with problem context and development of scientific understanding. A self-sufficient-oriented policy is said to be a category of food availability approach paradigm that can empirically not guarantee a food security for families and individuals. The better paradigm employs a food entitlement approach. Therefore, it is necessary to take a comprehensive policy that covers the dimensions of provisions, accessibility and food use as well as mitigation for the risk of them in an integrated micro-macro scale.

Referring to the food security paradigm, it is essential to employ an approach of micro-economic theory of production and consumption of agricultural products, mainly in supply. The agricultural productions include as follows: a) a subsidy of input price (fertilizers and seeds) can cause an input price cheaper than market price. It means that the input use is higher and therefore, it will increase production and profit of farming system per ha in consideration with an available technology. b) A 
subsidy of input price can provide incentive to farmers for adopting a more useful production technology; so, production and profit of farming system will be higher per ha. c) A positive impact on production and profit will be higher if an output price rises because an output price policy increases a government purchasing price (HPP, for example rice planting production). The consumptions of agricultural productions relate to a subsidy of output (rice) price. It means that the rice price is cheaper than the market price, and it will increase consumption per capita. Therefore, it will increase food accessibility for households under incomes.

\section{CONCLUSION}

A majority of the sub-districts in Wonogiri regency can be categorized into a secure food where it is reflected in the surplus food availability. This is affected by a government's role in implementing the maximum land utilization through an empowerment of the agricultural agency's staff.

However, Selogiri, Wonogiri and Jatisrono sub-districts were in the deficit food availability. It is reflected in a low index of food security as discussed above. The results of the study show that the subsdisricts own a lot of labors for migration so that more lands are less productive. In other words, they prefer to working outside their areas, although their lands are actually productive if they are utilized intensively.

Based on the findings, it is recommended that the government be necessary to prevent a problem from being food scarcity by encouraging the farmers for producing food to sustain food security and food autonomy. Some actions it takes are to encourage the farmers for utilizing 'unused' lands, providing good seeds for the farmers, and empowering the agricultural agency's staff to give counseling to them. Thus, they will prefer utilizing their lands to working outside their areas.

\section{REFERENCES}

Ariani, M. (2007), Penguatan Ketahanan Pangan Daerah untuk Mendukung Ketahanan Pangan Nasional, http://pse.litbang.pertanian.go.id, PSE Litbang Pertanian, accessed on 14 October 2013, 14.15, west Indonesian time.

Cengiz, T., F. Ozkok and C.K. Ayhan (2011), "Participation of the Local Community in the Tourism Development of Imbros (Gokceada)," African Journal of Agricultural Research, 6(16), 3832-3840.

Darwanto, D.H. (2005), "Ketahanan Pangan Berbasis Produksi dan Kesejahteraan Petani," Ilmu Pertanian, 12(2), 152-164.

Djaenudin, D., and M. Hendrisman (2008), "Prospek Pengembangan Tanaman Pangan Lahan Kering di Kabupaten Merauke," Jurnal Litbang Pertanian, 27(2), 55-62.

Hardjowigeno, H. (2007), Evaluasi Kesesuaian Lahan dan Perencanaan Tataguna Lahan, Gadjah Mada University Press, Yogyakarta.

Indrawan, I. (2012), "Pendekatan Change Management Pada Komoditas Pangan Strategis: Indonesia Feed The World Or The World Feed Indonesia?" AGRIMEDIA, 17(2), 9-19.

Marfai, M.A., and A. Cahyadi (2012), "Kajian Kesesuaian Lahan Untuk Mendukung Pengembangan Komoditas Pertanian di Wilayah Perbatasan Negara Republik Indonesia (Studi Kasus di Kabupaten Merauke, Provinsi Papua)," Jurnal Bumi Lestari, 12(2), 260-267.

Purnomo, D. (2009), "Fenomena Migrasi Tenaga Kerja dan Perannya Bagi Pembangunan Daerah Asal: Studi Empiris Di Kabupaten Wonogiri," 
Jurnal Ekonomi Pembangunan, 10(1), 84-102.

Roja, A. (2009), Ubi kayu Varietas dan Teknologi Budaya, Balai Pengkajian Teknologi Pertanian Sumatera Barat.

Rauf, A.W., and M.S. Lestari (2009), 'Pemanfaatan Komoditas Pangan Lokal Sebagai Sumber Pangan Alternatif di Papua," Jurnal Litbang Pertanian, 28(2), 54-62.

Rayes, L. (2007), Metode Inventarisasi Sumber Daya Lahan, Andi Offset, Yogyakarta.
Rugian, G. (2013), "Olahan dan Analisis Produksi Ekspor Hasil Perikanan terhadap DRB Kota Bitung," Jurnal EMBA, 1(3), 334-344.

Simatupang., P. (2008), Analisis Kritis Terhadap Paradigma Dan Kerangka Dasar Kebijakan Ketahanan Pangan Nasional, Pusat Analisis Sosial Ekonomi dan Kebijakan Pertanian.

Syahza, S. (2011), "Percepatan Ekonomi Pedesaan melalui Pembangunan Perkebunan Kelapa Sawit," Jurnal Ekonomi Pembangunan, 12(2), 299-301. 